\title{
THE FORMATION AND THE FUTURE POTENTIALS OF THE EIGHTH HUNGARIAN REGION
}

\section{László Péli*, Lilla Czabadai}

Szent István University, Gödöllő, Hungary

In the time of accession to the EU, Hungary drops to the second part of the programming period 2000-2006. The Central-Hungarian region (which includes the capital and Pest County) was classified as a less developed region, similarly to all of the six ,rural' regions and thus the area received the highest amount of the supporting sources. In the programming period 2007-2013, the Central-Hungarian region belonged to the transitional regions and so it received continuously decreasing subsidies. In the case of Budapest, the value of GDP per capita refers to the development, but based on the measurement, Pest County was supposed to belong to the transitional areas. Between the years 2014-2020, the whole area of the Central-Hungarian region was getting to the level of a developed region. It means that this area is not entitled to get Cohesion sources anymore. On the $30^{\text {th }}$ of October 2015, Pest County Assembly made a decision about Pest County's disruption and declared its intent to create a separated region. As long as the government stood for the idea and it met with a warm response in Brussels, Pest County could operate as an independent region from 2018. Our study will draw attention to the huge territorial differences between the capital and its agglomeration and the surrounding areas.

Keywords: regional policy, NUTS 2 level, Central-Hungarian region, regional differences

\section{Introduction}

According to the previous description, the primary goal of our study is to explore the territorial differences in the Central-Hungarian NUTS II region. Furthermore, our basic objective is to examine the causes of the economic and social issues in the case of both of the separated constituent administrative units. As a methodology we choose to analyse some useful studies and articles. The main question is whether the development or lagging behind the situation was typical for the NUTS III region in the programming period 2007-2013.
The Nomenclature of Units for Territorial Statistics system, in its everyday abbreviation NUTS system, is the only unified territorial classification system in the European Union. The framework has five levels, made up of three regional and two local levels. The forming and the regulation of the European Union's Cohesion Policy - similarly to some other specialties happen in NUTS II, regional level. The aim of the Cohesion Policy is - with providing balanced spatial development - to subserve the realizing the territorial differences between the different regions of the European Union. However, it is important to emphasize that there are a lot of

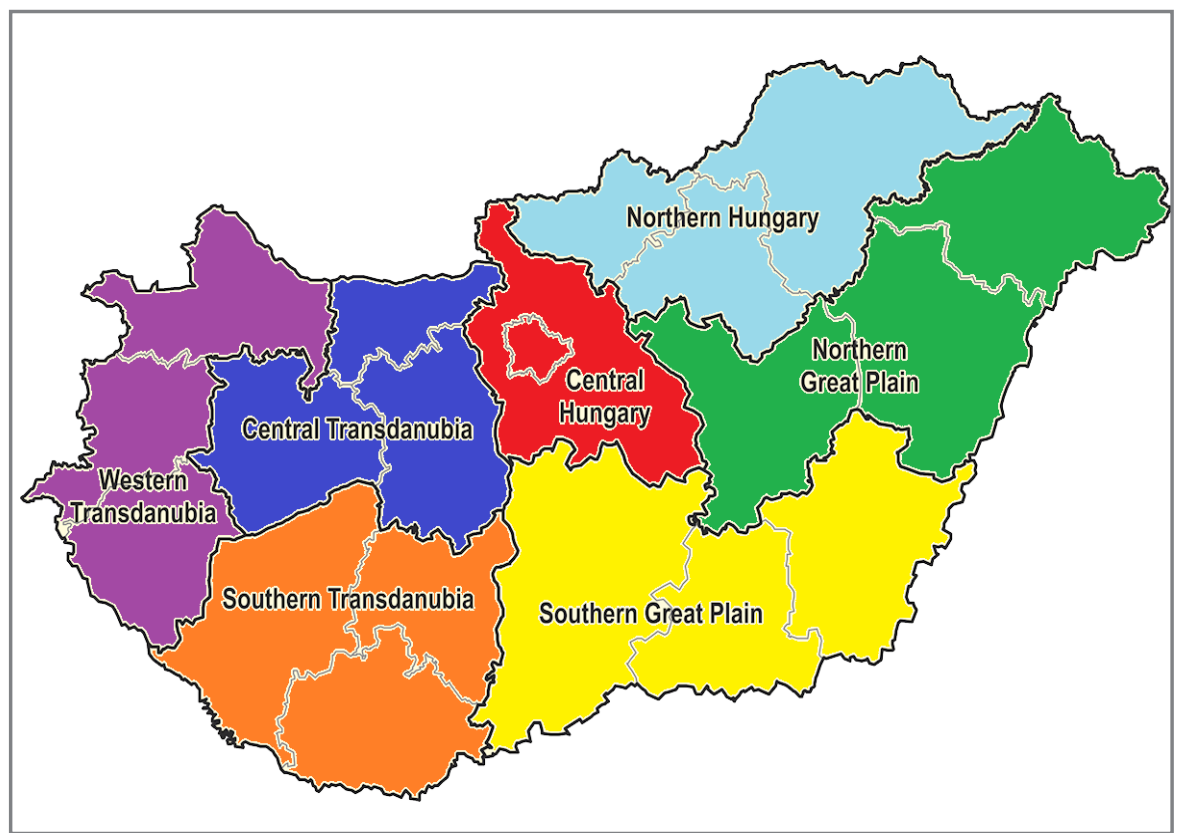

Figure 1 NUTS 2 regions in Hungary Source: hungaryforyou.wordpress.com

special facilities in the regional development in the Central Europe. We have different experiences within this region. The economical and social output of NUTS II in Hungary was determined by the Central Hungary, mainly Budapest (Egri et al., 2013).

The classification is always in the role of the member state, then it needs the approval of the EUROSTAT and later the European Commission comes to the decision. In 2004, when 10 states were joining the EU, the aspirants could choose from two alternative ways. The capital could be either classified as an independent NUTS II region (for example Slovakia, Czech Republic and later Romania) or according to the second way, the capital and other (already existing) administrative units constitute a NUTS II region together. Hungary chose the second possibility and thus Budapest and Pest County were merged into one NUTS II region (Figure 1).

In the categorising process of NUTS levels, the decision makers took only one standpoint into the account and hence its data determines the territorial definition up to these days. This aspect is evident in the area's population. Table 1 shows the minimal and maximal populations in the first three regional levels.

According to the above-mentioned criteria, both Pest County (with 1.2 million inhabitants) and Budapest (with 1.7 million people) have the rights to form an independent region.

By the measurement of GDP per capita, the Cohesion Policy of the EU distinguishes three levels of development. Based on this method, the EU distinguishes developed, transitional and less developed regions. In the time of the accession of 
Table 1 NUTS level's definition by population

\begin{tabular}{|l|c|c|}
\hline Level & Lower limit & Upper limit \\
\hline NUTS 1 & 3000000 & 7000000 \\
\hline NUTS 2 & 800000 & 3000000 \\
\hline NUTS 3 & 150000 & 800000 \\
\hline
\end{tabular}

Source: Szabó, 2015

Hungary to the EU, the state drops to the second part of the programming period 2000-2006. The Central-Hungarian region (which includes the capital and Pest (ounty) was classified as a less developed region, similarly to all of the six "rural" regions and thus the area received the highest amount of the supporting sources. In the programming period 2007-2013 the CentralHungarian region belonged to the transitional regions and so it received continuously decreasing subsidies. In the case of Budapest, the value of GDP per capita refers to development, but based on the measurement, Pest County was supposed to belong to the transitional areas. Between the years 2014-2020, the whole area of the CentralHungarian region was getting to the level of a developed region. It means that this area is not entitled to get Cohesion sources anymore. To ensure the right classification, the $\mathrm{EU}$ is about to deliver a new strategy in 2020 of a strong and effective system of economic governance that so far has been set up to coordinate political actions among the EU and national levels (Káposzta and Nagy, 2015).

Territorial differences can be experienced within Pest County, of course. This statement was supported by Kis and Goda (2013). As we can see from their research, there are huge territorial differences within Pest County that we cannot handle (or manage) as it is a homogeneous region. In another investigation (2013), Kis and co-authors proved that the competitiveness of the settlements decreases while their distance from Budapest increases. By the examination of the settlement-level, they could determine some relatively peripheral areas (Kis at al., 2013; Káposzta, 2014). Based on the research of the Ministry of National Economy (2015), we can conclude that the average development level of Pest County is much lower than in Budapest. Moreover, Pest County itself is divided by marked internal inequalities. These inequalities mainly arise among the suburban zone (agglomerative settlements which are in strong, daily relation with the capital) and the areas out of the agglomerative zone. Considering all of the economic and social development indicators, the outside zone and even certain parts of the agglomerative zone are lagging behind. Thanks to this kind of difference, these peripheral areas of Pest County (in the perspective of the development) can be rather compared with the neighbour territories of the less developed regions (Ministry of National Economy, 2015). The separation of the Central-Hungarian Region could be a solution to prevent the lagging behind of the internal peripheral areas and to start a development process as these peripheral territories could be the ones to get the cohesion funds.

\section{Materials and methods}

The methodology of our research was based on an analysis of the theoretical and historical backgrounds. Out of the statistical data, we have chosen the GDP per capita and the available EU subsidies for Pest County.

The thought of the separation of the region dates one and a half decade back, when in 2002 the Pest County Assembly initiated a referendum. The aim was to vote whether Pest County would have a chance to create an independent region. However, the Pest County Court didn't allow this initiation. Hence the idea of the seven region version was born at that time and it has been valid since the accession of Hungary to the EU.

After the accession, a three-year long moratorium came into force in the case of modification of NUTS system and thus the earliest date to modify the limitation of seven NUTS II regions could have been 2006. However,
Figure 2 The development of the NUTS system Source: pestmegye.hu in spite of the motivation of EUROSTAT, the modification failed in the absence of the Hungarian government's supporting activity. As we can see in the Figure 2., the member states have the possibility to modify the NUTS system every three years.

It was in 2009, when Hungary had a chance to divide again. The Hungarian government asked for delay but despite the permitted delay they didn't apply for the modification of NUTS system at the European Committee even in 2010.

In 2013 the application had no effect because the permitted new classification would come in force on the $1^{\text {st }}$ of January 2015. (The modifications which are supported by the national government, the European Committee and the EUROSTAT come into force in the second following year after the application was submitted.) As this date is the second year of the seven-year planning period, the EU subsidies have already declared that the process of division wouldn't start even in 2013.

On the $30^{\text {th }}$ of 0 ctober 2015, the Pest County Assembly made a decision about Pest County's disruption and declared its intention to create a separated region. As long as the government stood for the idea and it met with a warm response in Brussels, Pest County could operate as an independent region from 2018.

\section{Results and discussion}

Why is the separation so important? Pest County's self-sufficiency is essential because the level of development of the regions is determined by the GDP per capita in comparison to the EU. According to this, the following data has been created:

$\square$ the measurement of the cohesion and rural development,

$\square$ the range of eligible activities and the rate of co-financing,

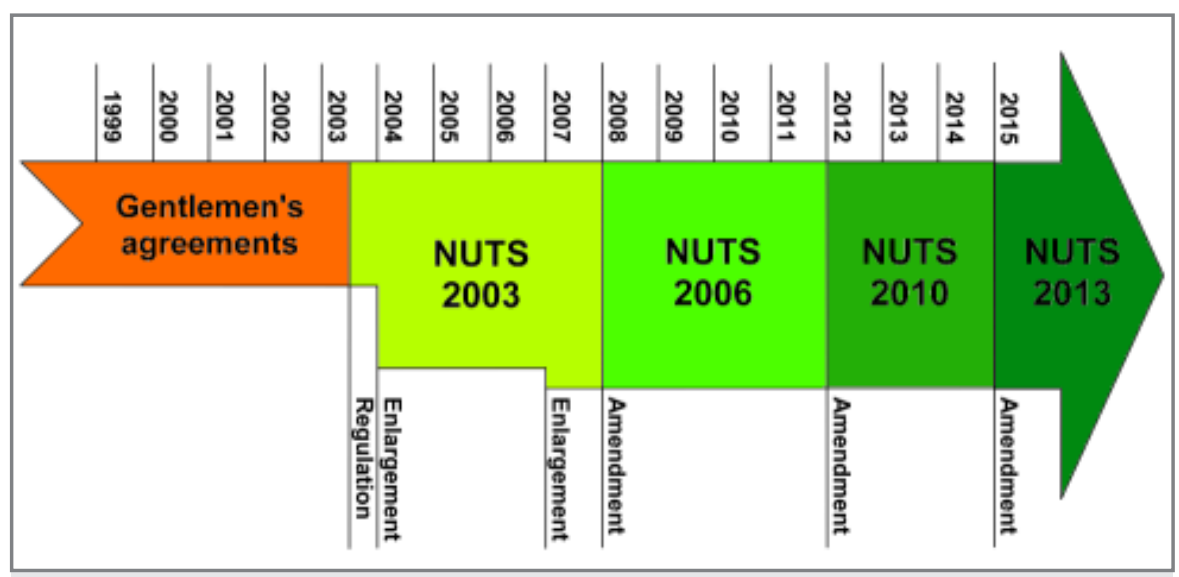




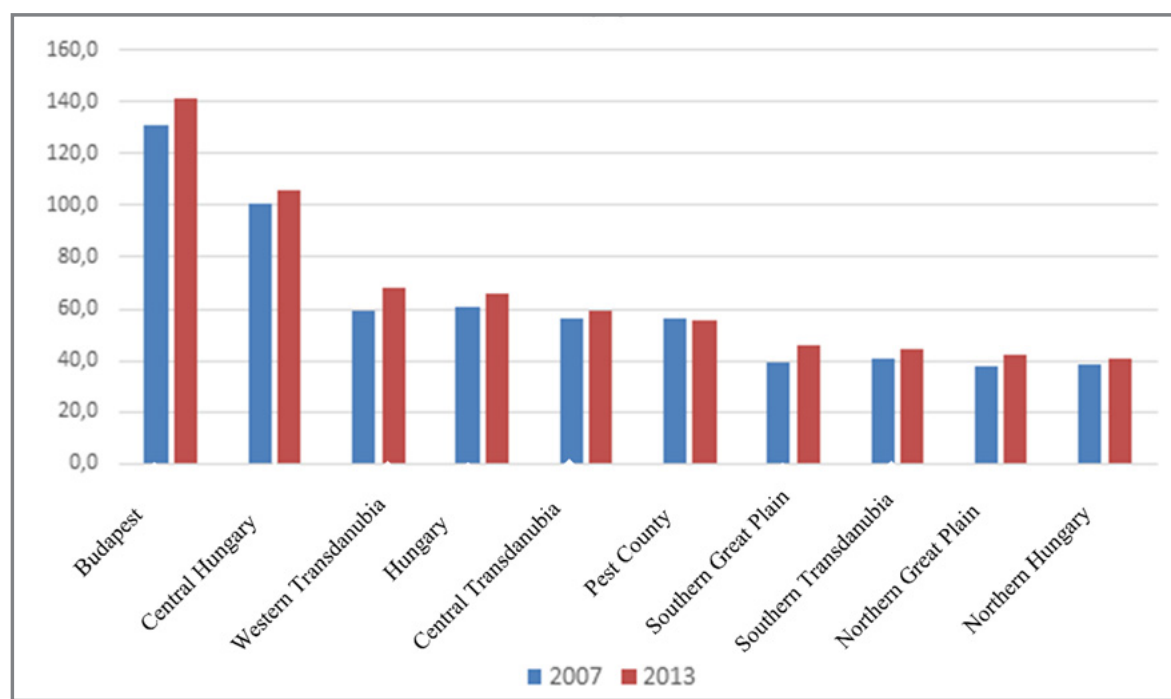

Figure 3 GDP per capita in the average percentage of EU 27 (based on PPSin \%) Source: (sath, 2015

$\square$ source-concentrating limitations in relation with support,

$\square$ the measurement of supports for enterprises (maximum supporting intensity) (Csath, 2015).

As we mentioned above, in the $\mathrm{EU}$, the measurement of support per region is determined by the GDP per capita. The way of this calculation is that what the relation of the percentage of the GDP per capita to the average of the EU is. The results appeared in a three-point scale:

$\square$ GDP per capita is under the average of the EU 27: less developed region

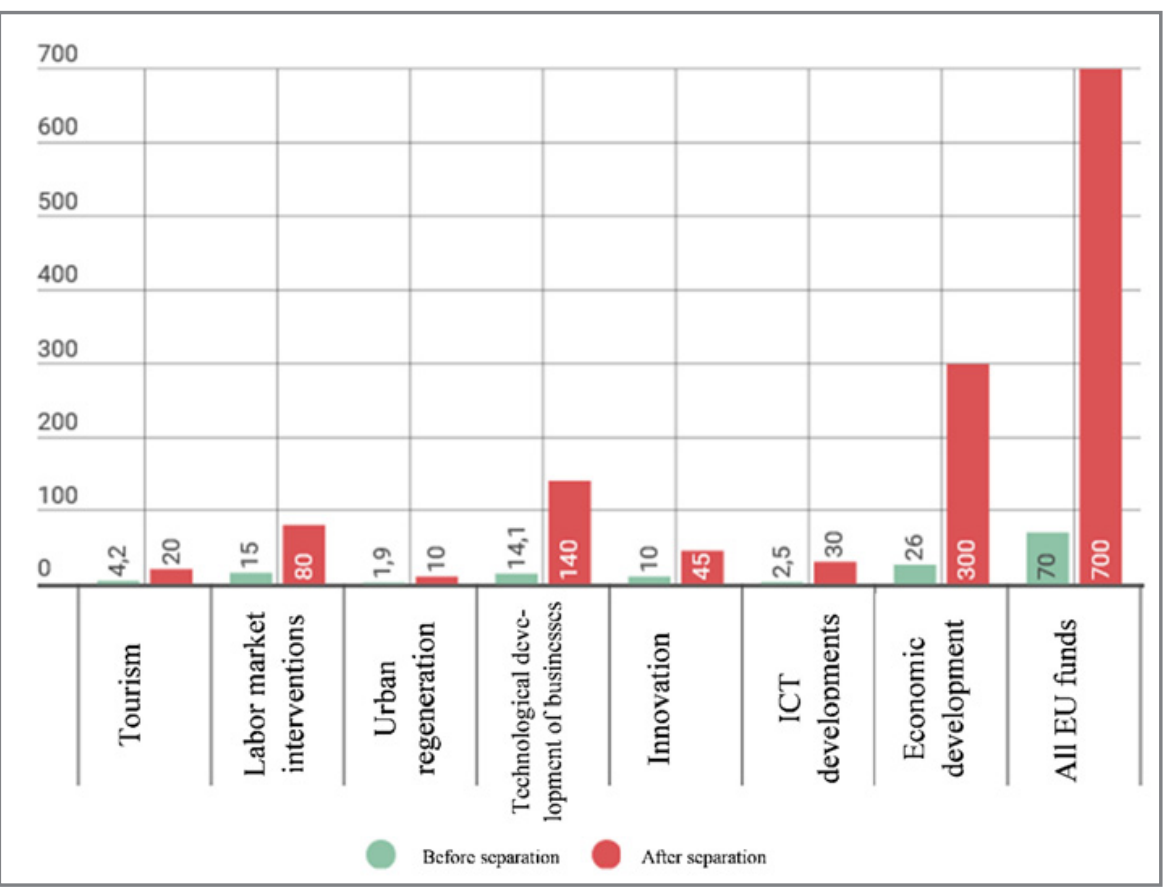

Figure 4 Available EU subsidies for Pest County at 2014-2020 in bill. HUF Source: Dzindisz, 2015 $\square$ GDP per capita is between $75-90 \%$ of the EU 27 's average: transition region

$\square$ GDP per capita above $90 \%$ of the EU 27's average: developed or competitive region

This definition also determines the rate of the obligatory national contribution besides the determination of the EU subsidies. If the member state didn't assume this co-financing, then it couldn't reach this amount of supports.

Based on the above-mentioned limitation - the previous planning period qualification - the capital's outstanding into the category of the transitional regions. The performance influences the region's aim to get economic efficiency in planning period 20072013 of the Hungarian counties and the capital is shown in the Figure 3.

As the Figure 3 shows, Budapest has an absolutely leading position in ranking, although Pest County has about 55\%. Certainly, it doesn't mean that it could motivate any kind of development in Pest County. The important thing is that their merged, aggregated average seems positive in the statistical point of view.

Two less developed Trans-danubian regions follow Budapest and the Central-Hungarian region, namely the West-Transdanubian and the Central-Transdanubian one. After those, Pest County is the next one, and its position is therefore in the middle of the field, as the rest four regions come after it.

If we analyse the development process under the planning period and not just under the ranking position in 2013, we could get a totally different result. It is clear, that the most highlighted development level belongs to Budapest which is followed by the West-Transdanubian region. Overall, we can conclude that all the seven Hungarian NUTS II regions developed between the years 2007-2013. If we examine separately the two administrative units (Budapest and Pest County) of the Central-Hungarian region, we could face some mismatching data. Based on this, Pest County is the only area under the 2007-2013 programming period which was not developed and what is more, its economic efficiency decreased to $55 \%$ from $56 \%$. We could talk about a significant problem because in 2004 this value was $40 \%$ which means $16 \%$ rising in the first three years, while in the seven year planning period it means $1 \%$ decrease as the only region in the country. In the time of the programming the ongoing 2014-2020 planning period, the Central-Hungarian region has already belonged to the developed (competitive) regions and according to this, the region is entitled for slight amount of the $\mathrm{EU}$ supports. Figure 4 contains the most significant details and results of this research. It shows eight categories of the ongoing limitation and the measurements of the entitled spheres to get the subsidies.

Supports in the relation with the tourismdevelopment would be five times higher, while labour-market targeted subsidies could increase by five and a half times than before the separation. Similarly to the previous spheres, the sphere of urban regeneration and innovation development purposes could get five times more support after the division. Three the most 
significant sectors - approximately with ten or twelve times more subsidies will be the developments of small and medium-sized enterprises, the support of info-communicational technologies and the economic-development arrangements. At the same time, the separation of some settlements with agricultural characteristics in the Budapest agglomeration should be considered in accordance with the rural policy goals (e.g. relations between the urban and rural areas - see Ritter, 2014) of the EU and Hungary, as well.

To summarise, we can say that current approximately 70 billion HUF supporting amount could be ten times higher after the independent NUTS II region establishment. We can clearly see from our study that the previous and the present programming period for Pest County, the symbiosis' with Budapest, was disadvantageous. During the two planning periods, the county didn't receive its deserved European Union subsidies. Based on the previous analysis and data, these facts obstruct the county to improve its competitiveness. However, the winner of this integration was Budapest, as without Pest County the capital could not be able to reach such a big amount of the EU supports neither in 2004-2006 nor in 2007-2013. With these aids, Budapest's development and economic performance is unbreakable. According to the latest research, only $20 \%$ of the obtained tenders (applications) were given to Pest County and the remaining $80 \%$ went to the capital, Budapest. Thanks to this information, it is necessary to present this "development-gap" because if the capital develops continuously, Pest County will lag behind.

\section{References}

A PIECE OF HUNGARY for you. 2015. https://hungaryforyou.wordpress.com/2013/08/26/ counties-districts/ (accessed: 2015.11.20.)

CSATH, M. 2015. Pest County - as a part of the Central-Hungarian Region - the changes in the economic and social status between 2007-2013. Pest County's website http://www.pestmegye.hu/images/2015/Dokumentumok/Onallo_Pest_megye_ dokumentumok/PDF/Pest_megye_NUTS2_dokumentum_2015.10.30._final.pdf (accessed: 2015.11.20.)
DZINDZISZ, S. 2015. Is it possible to escape from the stranglering embrace of Budapest? Pest County's website: http://www.pestmegye.hu/hirek-altalanos/ki-lehet-eszabadulni-budapest-fojtogato-olelesebol-dzindzisz-sztefan-cikke (accessed: 2015.11.20.)

EGRI, Z. - PARASZT, M. - MOLNÁR, M. 2013. A regionális növekedés minőségi és/vagy térbeli dimenziói Közép - Kelet - Európában Kitekintés - Perspective. In Revista de Stiinta si Cultura vol. 42, 2013, no. 19, pp. 31-37.

KÁPOSZTA, J. - NAGY, H. 2015. Status Report about the Progess of the Visegrad Countries in Relation to Europe 2020 Targets. In European Spatial Research and Policy, vol. 22, 2015, no. 1, pp. 81-99. D0I: 10.1515/esrp-2015-0018. http://esrap.geo.uni.lodz.pl/ index.php?page $=\mathrm{v} 22 \mathrm{n} 1$

KÁPOSZTA, J. 2014. Main correlation of the territorial differencies. In Gazdálkodás, vol. 58, 2014, no. 5, pp. 399-412. ISSN 0046-5518.

KIS, M. - GODA, P. - PÉTER, B. 2013. Competitiveness map of the settlements in Pest county. In Review on Agriculture and Rural Development, vol. 2. 2013, no. 1, pp. 301-306. ISSN 2063-4803.

KIS, M. - GODA, P. 2013. Competitiveness map of Pest County's settlements. In Lukovics, M. - Savanya, P. (ed.) 2013. New emphasis in territorial development, Szeged : JATEPress, 2013, pp. 116-128.

MINISTRY for National Economy. 2015. Test riport about the possibility of The CentralHungarian Region incidental separation. Budapest, November, 2015.

SZABÓ, P. 2005. The formation and transformation of the NUTS system. In Comitatus, vol. 15,2005, no. 8-9, pp. 7-14.

RITTER, K. 2014. Possibilities of local economicdevelopment (LED) inlaggingruralareas.In Acta Carolus Robertus, vol. 4, 2014, no. 1, pp. 101-108.

\section{Contact address}

László Péli PhD, Szent István University, Faculty of Economics and Social Sciences, Institute of Regional Economics and Rural Development, H-2100 Gödöllő, Páter Károly str. 1., 疋 +3628522 000/ 2374, e-mail: Peli.Laszlo@ gtk.szie.hu

口n 